\title{
Identification of Ectoparasite and Prevalence Male and Female of Cantang Grouper Fish (Epinephelus fuscoguttatus $x$ Epinephelus lanceolatus) in Aquaculture Paluh Pisang Mas Deli Serdang, North Sumatera Province
}

\section{Yusni E*, D Wulandari and Fuad SP}

Department of Aquatic Resources Management, Agribisnis, Faculty of Agriculture, Universitas Sumatera Utara, Medan, Indonesia

*Corresponding Author: Yusni E, Department of Aquatic Resources Management, Agribisnis, Faculty of Agriculture, Universitas Sumatera Utara, Medan, Indonesia.
Received: January 04, 2021

Published: February 26, 2021

(C) All rights are reserved by Yusni E., et al.

\begin{abstract}
The identification of ectoparasites with 30 samples of fish was infected male and female of Cantang Grouper (Epinephelus fuscoguttatus $x$ epinephelus lanceolatus) in Paluh Pisang Mas Pond, Hamparan Perak District, Deli Serdang Regency, North Sumatra and to determine the prevalence of Cantang Grouper (Epinephelus fuscoguttatus x epinephelus lanceolatus) in Paluh Pisang Mas Pond. There are four types of ectoparasites was infected in Cantang Grouper fish in Paluh Pisang Mas Pond, namely Zeylanicobdella sp., Brooklynella hostilis, Caligus sp. and Dactylogyrus sp. The highest prevalence rate was found of Zeylanicobdella sp. with a value of $26.66 \%$ in the oral organs and $23.33 \%$ in the mucous organs with the category of frequent infections. Brooklynella hostilis with a value of $23.33 \%$ with the category of frequent infections. Genus Caligus sp with a value of $10 \%$ with the category of frequent infections and genus Dactylogyrus sp. with a value of $16.66 \%$ in the category of frequent infections. The Zeylanicobdella sp, was found highest of 20 types, Brooklynella hostilis of 11 in female, and 16 types and 3 types was found in male, but ectoparasite of cligus sp was found highest of 6 types in male and not infected by female. Compare of Dactylogyrus sp was found highest of 5 types in female, and 2 type in male.
\end{abstract}

Keywords: Cantang Grouper Fish; E. fuscoguttatus x epinephelus lanceolatus) Ectoparasite; Prevalence

\section{Introduction}

Cantang Grouper (Epinephelus sp.) Is a hybrid species of male and female of tiger grouper, Epinephelus fuscoguttatus Kertang grouper, Epinephelus lanceolatus, have been carried out by the Brackish Water Cultivation Development Center (BADC), since Sitobondo (2009). The Cantang grouper morphologically is similar to two species broodstock, meanwhile growing perform was better compared the Tiger or Giant Grouper. In addition, Cantang Grouper is more adaptive and resistant to certain diseases.
The aquaculture pond in Paluh Pisang Mas, Hamparan Perak District, Deli Serdang Regency, North Sumatra is a business pond that has been running from \pm 10 years. The Cantang grouper (Epinephelus $\mathrm{sp}$ ) fish whose seeds are imported from Situbondo district, East Java Indonesia. The Cantang Grouper fish is hybrid species for female Tiger Grouper (Epinephelus fuscoguttatus) and male Kertang Grouper, (Epinephelus lanceolatus), it has been carried out by the Brackish Water Cultivation Development Center (BADC) [1]. Until now, Situbondo district is one place was succeeded in carrying out the process of crossing (hybrid) of Cantang Grouper Fish. 
Identification of Ectoparasite and Prevalence Male and Female of Cantang Grouper Fish (Epinephelus fuscoguttatus x Epinephelus lanceolatus) in Aquaculture Paluh Pisang Mas Deli Serdang, North Sumatera Province

One of the obstacles faced of Cantang Grouper fish in this pond was observed when the checking one by one of fish, several fish were showing signs of disease, such as white spots attached to the fish's from outer body parts. Fishermen or workers call them parasites like protozoa. This problem always occur within one month and when the checking of fish.

The problems in Paluh Pisang Mas Pond also often occur, especially when the 10-20 days or when the fish was 4 inch of age seedlings are stocked, due to changes in the water from initial place. Usually, after fishermen or workers know that there are signs that the fish is suffering from the disease, and they will give medicine such as liquid. The object of this research are to looked how much male and female were infected by ectoparasite in Paluh Pisang Mas Pond. Because of that this case need to investigat infection ectoparasite for the Cantang Grouper fish.

Time and place of research

This research was conducted from September to October 2020. The sample of fish were taken in Paluh Pisang Mas Pond, Paluh Kurau Village, Dusun 14, Hamparan Perak Sub-District, Deli Serdang Regency, North Sumatra Province and research of ectoparasite identification was done in the Government Laboratory of Technical Implementation of Fishery Product Quality (UPT PMHP) Medan.

\section{Material and Methods}

The sampling method was carried out by random sampling (randomly) of 30 fish male and female in Cantang Grouper in Paluh Pisang Mas pond. The sample were measured of body weight and body length male and female than examined of ectoparasites with scraping the mucus in entire outer body and placing in a glass slide, then observing the results of scrapings under a microscope with a magnification of 4 to 40 times. Second, cut fish fins starting dorsal fin, pectoral fin, pelvic fin, caudal fin, anal fin and puted down in the glasses preparation containing physiological $\mathrm{NaCl}$, then put down the scrapings under the microscope with a magnification of 4 times up to 40 times then taken fiture. Third, cut down in gill cover (operculum) and fish gill filaments then transfer them to the glass preparation containing physiological of $\mathrm{NaCl}$. Scrape the mucus from operculum and gills, then observed the scrapings under the microscope at a magnification of 4 to 40 times. Fourth, remove the mucus in the oral cavity and place the scrapings on the glass prepa- ration containing physiological of $\mathrm{NaCl}$, then carry out the observation under the microscope with magnification of 4 to 40 times.

\section{Prevalence of ectoparasites}

The research data were presented in tables and figures after analyzed descriptively based on the identification results of the Cantang Grouper (Epinephelus fuscoguttatus x E. lanceolatus) then the infections ectoparasite prevalence of fish were calculated by using the formula:

$$
\text { Prevalence }=\frac{\mathrm{N}}{n} \times 100 \%
$$

Information:

- Prevalence: Prevalence (100\%)

- $\quad \mathrm{N}$ : Total fish infected of parasites (tails)

- $\mathrm{n}$ : Total of samples observed (tails)

The supporting parameters in this study were taken from size, body length, body weight and genital of fish. The measured of parameter in this study were used an Guidelines infection category based on prevalence by Williams [2] and were shown in table 1.

\begin{tabular}{|l|c|c|c|}
\hline No. & Prevalence & Category & Information \\
\hline 1. & $100-99 \%$ & Always & Very severe infection \\
\hline 2. & $98-90 \%$ & Almost Always & Severe infection \\
\hline 3. & $89-70 \%$ & Usually & Moderate infection \\
\hline 4. & $69-50 \%$ & Very often & $\begin{array}{c}\text { Infections are vey } \\
\text { frequent }\end{array}$ \\
\hline 5. & $49-30 \%$ & Generally & Common infection \\
\hline 6. & $29-10 \%$ & Often & Frequent infections \\
\hline 7. & $9-1 \%$ & Sometimes & Moderate infection \\
\hline 8. & $<1-0,1 \%$ & Rarely & Infection is rare \\
\hline 9. & $<0,1-0,1 \%$ & Very rarely & Infection is very rare \\
\hline $10 /$. & $<0,01$ & Almost never & Infection never \\
\hline
\end{tabular}

Table 1: Guidelines infection Categories Based on Prevalence. by Williams (1996).

\section{Result and Discussion}

The total of 30 male and female of Cantang grouper fish were identified for body weight and length between of 118-430 grams and 19-30 cm. All of fish samples were examined infected of para- 
sites in the mucous organs, fins, gills and mouth. The ectoparasite were identified of fish in this pond before this no body was investigate or identification of infected endoparasite in Cantang grouper fish in Paluh Pisang Mas Pond, Hamparan Perak District, Deli Serdang Regency, North Sumatra. After this study observed the infection of ectoparasites in fish was found of 4 types endoparasite was infected of Cantang Grouper (Epinephelus fuscoguttatus x Epinephelus lanceolatus) male and female fish, and can shown in table 2.

\begin{tabular}{|l|c|c|c|}
\hline Types of Parasites & Male & Female & $\begin{array}{c}\text { Total Parasites } \\
\text { (ind) }\end{array}$ \\
\hline Zeylanicobdella sp. & 16 & 20 & 36 \\
\hline Brooklynella hostilis & 3 & 11 & 14 \\
\hline Caligus sp. & 6 & 0 & 6 \\
\hline Dactylogyrus sp. & 2 & 5 & 7 \\
\hline
\end{tabular}

Table 2: Identification of ectopararasites attack to the Cantang Grouper Fish in the mucous organs, fins, gills and mouth.

The identification results of ectoparasites dominated was found in mucus, fins, gills and mouth organs, the parasite was found is Zeylanicobdella sp. There are of 36 total parasites (ind) was infacted to the fish. Followed the type of parasite of Brooklynella hostilis was found of 14 type, the Caligus sp was infected of 6 fish, the Dactylogyrus sp and was found infected of 7 of fish. The Zeylanicobdella sp, Brooklynella hostilis and Dactylogyrus sp was found higher of 20 - 16 (ind), (11 - 3 (ind) and of 5 -2 (ind) in female compared to male fish. The Caligus sp was higher of 6 (ind) in male but do not found parasite in female (Figure 1-5).

During fish growing in the pond, in faced grouper will see the parasites were attack in the body surface or skin and pale when the excessive in mucus. Organisms were attack the surface of the body fish can infected from bacteria, viruses, fungi or others. This is were see from the phenotypic traits and characters. For the male fish was difference as the body color look like blackish brown and longer, compared to the female body color bright and round [1].

Fish infected of ectoparasites can see in their skin and will rub their bodies to against the objects around them, often causing new wounds which can lead to secondary infection, while of gill disease is rather difficult to detect early because it attacks the inside of the body fish. One way for that is considered effective enough to detect in gill ectoparasite infestations is to observe of fish behavior [2].

\section{Morphology of Male and Female of Cantang Grouper Fish}

Based on the research have been conducted to female and male of grouper fish (Figure 1a and 1b), and female have a body weight and fatter body compared the male. Meanwhile, male grouper fish not really different compared to body length in female fish. In addition, female have a longer body size than male grouper fish. While the body color of male and female grouper fish is the same, namely the head has a shiny gray color, the back color is dark, while the belly and fins are silvery in color (Figure 1).

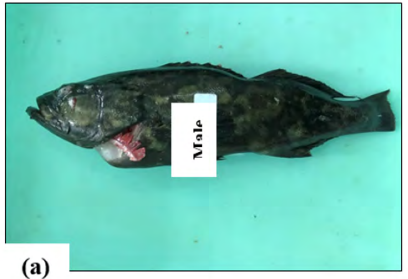

(a)

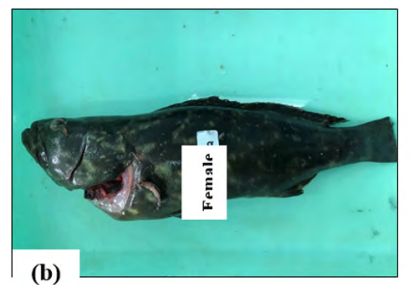

(b)
Figure 1: (a.) Male and (b) Female, of Cantang Grouper fish.

The organs of male and female of Cantang Grouper fish was infected ectoparasite as figure 2-5.

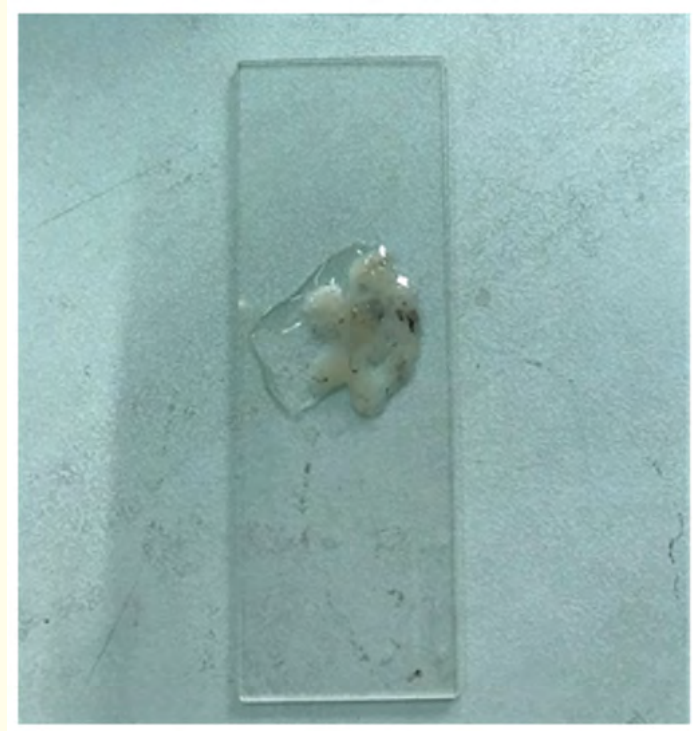

Figure 2: The mucus at scale. 


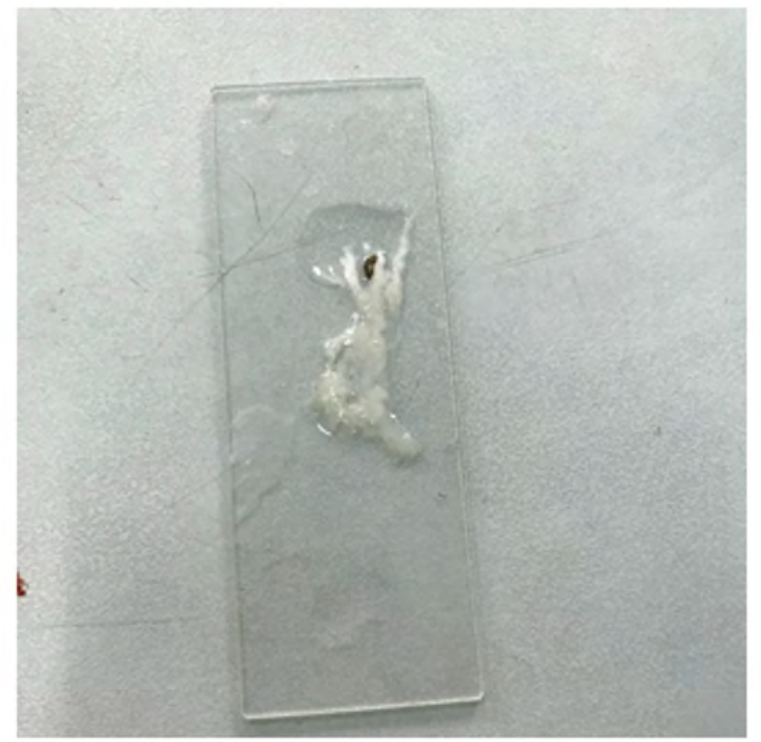

Figure 3: The mucus at mouth.

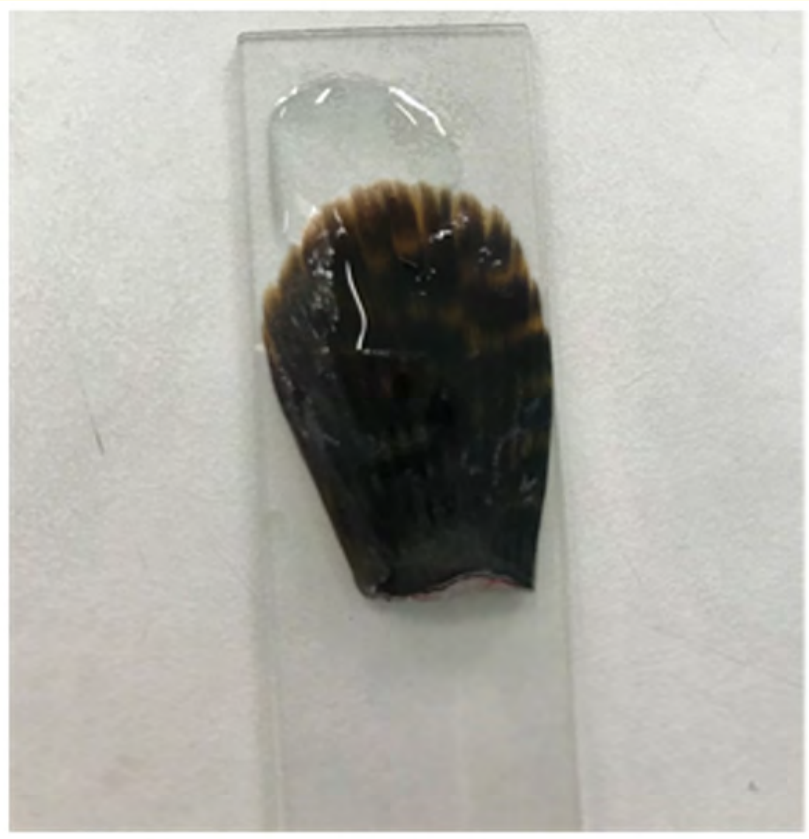

Figure 4: The fin.

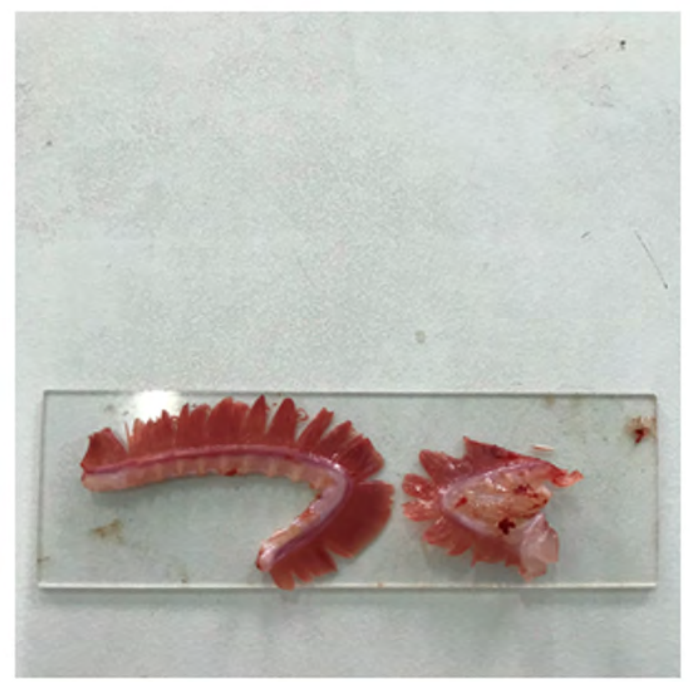

Figure 5: The gill.

\section{The male Cantang Grouper Fish}

The male of grouper fish was found ectoparasites with the genus of Zeylanicobdella sp. This infection was found in the mucus organs, fins and mouth. In the mucous organs was found of 4 total parasites (ind) in the fin and of 6 parasites (ind) in the oral. Figure 6 - 9 was shown infection of ectoparasite in each organs..
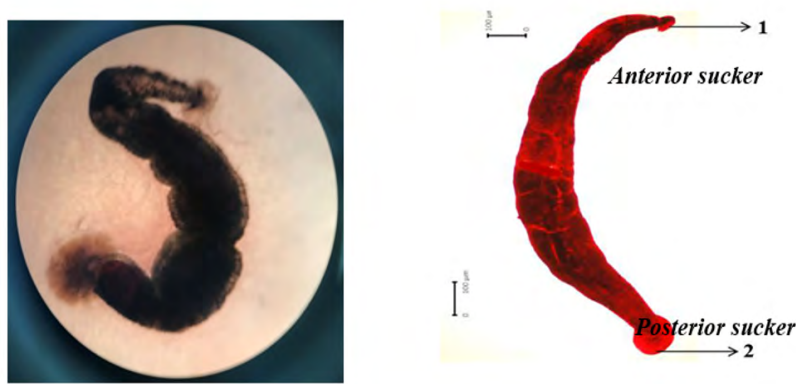

(a)

(b)

Figure 6: (a) Ectoparasites Zeylanicobdella sp.shown in fins, mucus and mouth of male Cantang Grouper fish. (b) Similar Source by Mahasri., et al. [4]. 
The genus of Brooklynella hostilis infection was found only in mucus organs. The total number of parasites in male was found of 3 (ind).
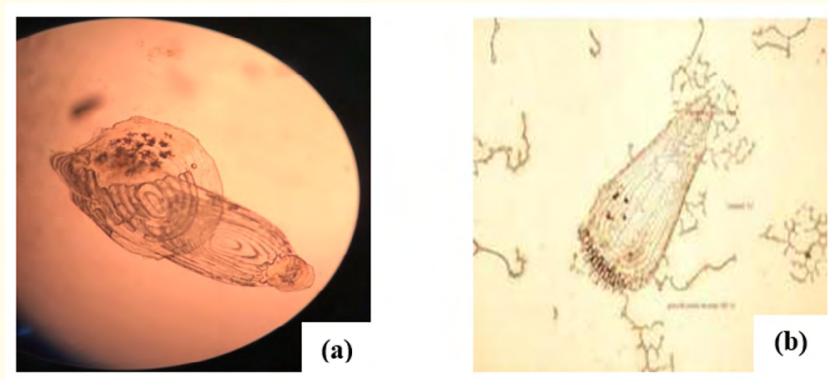

Figure 7: (a) Ectoparasites of Brooklynella hostilis was found only in mucus (b) Similar Source by Gusriyanti., et al. [5].

The Genus of Caligus sp also was found infection in the mucus organs only. The total number of parasites infecting in male was found of 6 (ind).

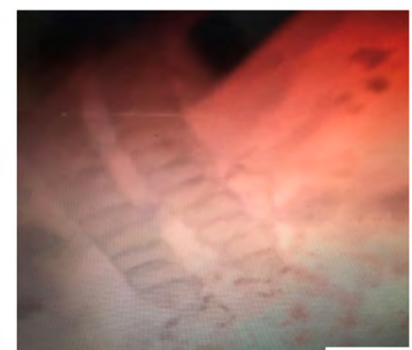

(a)

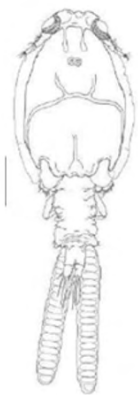

(b)

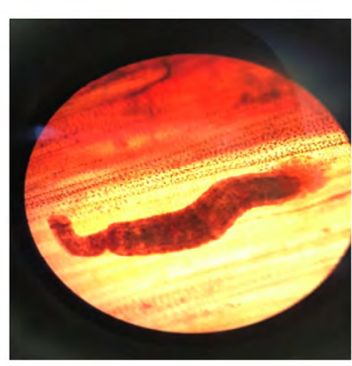

(a)

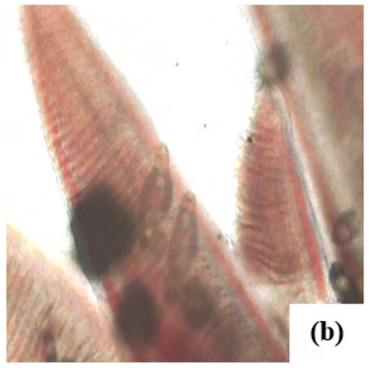

(a)

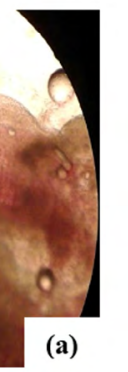

(b)
Figure 9: (a) Ectoparasites of Dactylogyrus sp was found in the gill (b) Similar Source by Nofyan., et al. [7].

\section{Female cantang grouper fish}

In the ectoparasites of female grouper fish was found of genus Zeylanicobdella sp. The infection was found in the mucus organs, fins and mouth, the total of parasite was found of 7 (ind) and in the oral organs was found of 6 parasites (ind).

Figure 8: (a) Ectoparasites of Caligus sp. in male Cantang Grouper fish was found in the mucus (b) Similar Source by Wiguna., et al. [6].

The Ectoparasites of Dactylogyrus sp infection was found in the gills only. The total number of parasites infecting was found of 2 (ind).

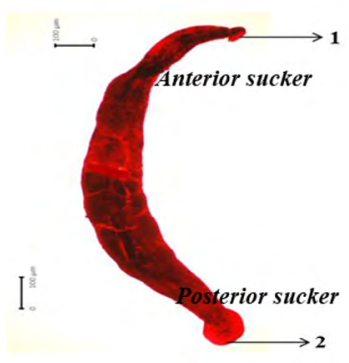

(b)
Figure 10: (a) Ectoparasites Zeylanicobdella sp. in female Cantang Grouper in the organs of the fins, mucus and mouth (b) Source: Mahasri., et al. [4].

The genus of Brooklynella hostilis infects was found in female Cantang Grouper only the mucus organs. The number of parasitic markers (ind) in female Cantang Grouper was f of ound 11 (ind). 

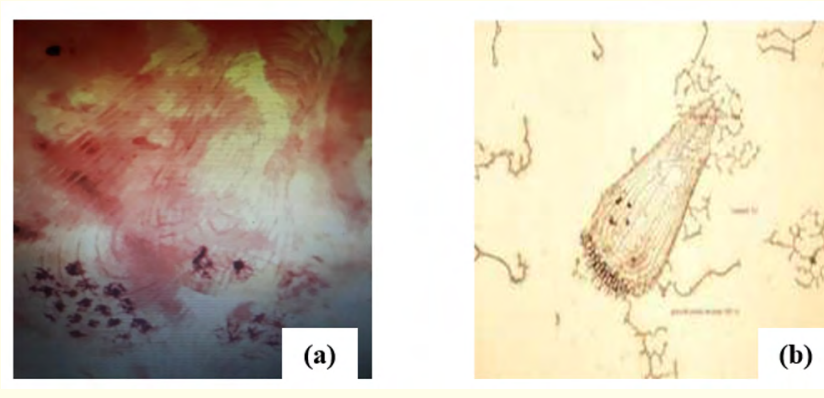

Figure 11: (a) Ectoparasites Caligus sp. in female Cantang Grouper fish in the organs of mucus (b) Source: Wiguna., et al. [6].

The ectoparasites of Dactylogyrus sp was infected in the gills to female Cantang Grouper only. The total number of parasites (ind) infecting female Cantang Grouper was found of 5 (ind).

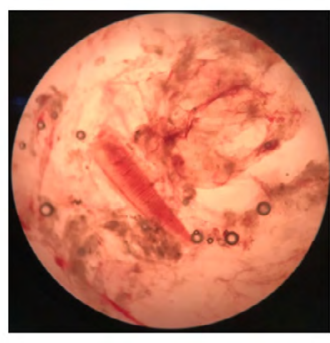

(a)

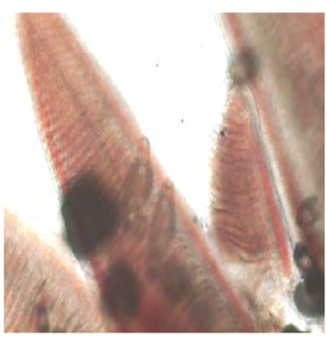

(b)
Figure 12: (a) Ectoparasites Dactylogyrus sp infection in the gill only in female Cantang Grouper fish in (b) Source: Nofyan., et al. [7].

\begin{tabular}{|c|c|c|c|c|c|c|}
\hline Fish & Weight & Length & Mucus & Fin & Gill & Mouth \\
\hline \multirow{2}{*}{ Male } & 239.384 & 24.31 & 1.00 & 46 & 15 & 46 \\
& $(31.077)$ & $(1.094)$ & $(277)$ & $(268)$ & $(104)$ & $(215)$ \\
\hline \multirow{2}{*}{ Female } & 199.235 & 23.65 & 1.06 & 41 & 29 & 35 \\
& $(18.009)$ & $(636)$ & $(290)$ & $(243)$ & $(166)$ & $(170)$ \\
\hline \multirow{2}{*}{ Total } & 216.633 & 23.93 & 1.03 & 43 & 23 & 40 \\
& $(16.977)$ & $(587)$ & $(200)$ & $(177)$ & $(104)$ & $(132)$ \\
\hline
\end{tabular}

Table 3: Mean and Standart Error of body weight, length and some organs was found infection of ectoparasites in Cantang grouper fish.
Tthe infect of parasites in male Cantang Grouper was found higher value of 239,384 grams compared female fish but for length not really differences thatt is value of $24.51 \mathrm{~cm}$ and of $23.65 \mathrm{~cm}$ in female. However the weight no effect for infection of ectoparasite in fish, some organs as fin and mouth was found higher value of 46 (ind) in male and lower value of 41 (ind) was found in female. But in gill was found higher value of 29 (ind) female compared to male with value of 15 (ind). In mouth was found higher value of 46 (ind) was found in male compared to female was found lower value of 35 (ind), this is similar results by Williams [2].

Based on the results of this research have been conducted, it is known that ectoparasite infected for female Lindu Fish (Oryzias sarasinorum) [8]. But this is due to differences in condition factors with indications of biological characteristics of fish such as obesity, suitability of the environment or gonad development and weight of food contained in the digestive tract of these fish. In this study, was found that the average body weight value of female tuna is higher than the average body weight value of male (Table 3). According to Gani., et al. [8], the differences of condition factors are once indication of various biological characteristics of fish such as obesity [9], suitability of the environment can effect to development of gonads. The value of the fish condition factor also influenced to maturity of the gonads, influenced for the weight, digestive tract as well as the size, age of the fish.

\section{Prevalence of Ectoparasites}

The prevalence of ectoparasites was found to infect the mucous organs, fins, gills and mouth of the Cantang Grouper, the differences values for each genus. Data results was calculated on ectoparasite prevalence in Cantang Grouper fish (Table 4,5).

The prevalence of ectoparasites infection in male grouper was found of the genus Zeylanicobella sp. The value was found of 10\% in mucous organs, of $10 \%$ in the fins and of $13.33 \%$ in the oral organs. And also the ectoparasite prevalence of Brooklynella hostilis was found of $6.66 \%$ in mucous organs alone. Meanwhile, the prevalence value of ectoparasite type Caligus sp was found of $10 \%$. The ectoparasites prevalence of Dactylogyrus sp was found of $6.66 \%$ as shown in table 4.

The prevalence of ectoparasites infection of female grouper was found of the genus Zeylanicobella sp, The prevalence of ectopara-

Citation: Yusni E., et al. "Identification of Ectoparasite and Prevalence Male and Female of Cantang Grouper Fish (Epinephelus fuscoguttatus $x$ Epinephelus lanceolatus) in Aquaculture Paluh Pisang Mas Deli Serdang, North Sumatera Province". Acta Scientific Nutritional Health 5.3 (2021): 61-68. 


\begin{tabular}{|c|c|c|c|c|}
\hline $\begin{array}{c}\text { Total of } \\
\text { Samples } \\
\text { Examined }\end{array}$ & Organs & Types & $\begin{array}{l}\text { Total of } \\
\text { Infected } \\
\text { Samples }\end{array}$ & $\begin{array}{c}\text { Prevalence } \\
\text { (\%) }\end{array}$ \\
\hline \multirow{6}{*}{30} & & $\begin{array}{l}\text { Zeylanicob- } \\
\text { della sp. }\end{array}$ & 3 & \multirow{3}{*}{$\begin{array}{c}10 \\
6,66 \\
10\end{array}$} \\
\hline & Mucus & $\begin{array}{c}\text { Brooklynella } \\
\quad \text { hostilis }\end{array}$ & 2 & \\
\hline & & Caligus sp. & 3 & \\
\hline & Fin & $\begin{array}{l}\text { Zeylanicob- } \\
\text { della sp. }\end{array}$ & 3 & \multirow{3}{*}{$\begin{array}{c}10 \\
6,66 \\
13,33\end{array}$} \\
\hline & Gill & $\begin{array}{c}\text { Dactylogyrus } \\
\text { sp. }\end{array}$ & 2 & \\
\hline & Mouth & $\begin{array}{l}\text { Zeylanicob- } \\
\text { della sp. }\end{array}$ & 4 & \\
\hline
\end{tabular}

Table 4: Total Prevalence ectoparasites infection of male grouper fish.

\begin{tabular}{|l|l|c|c|c|}
\hline $\begin{array}{c}\text { Total of } \\
\text { Samples } \\
\text { Examined }\end{array}$ & Organs & Types & $\begin{array}{c}\text { Total of } \\
\text { Infected } \\
\text { Samples }\end{array}$ & $\begin{array}{c}\text { Prevalence } \\
\text { (\%) }\end{array}$ \\
\hline \multirow{3}{*}{30} & Mucus & $\begin{array}{c}\text { Zeylanicob- } \\
\text { della sp. } \\
\text { Brooklynella } \\
\text { hostilis }\end{array}$ & 4 & 13,33 \\
\cline { 2 - 4 } & Fin & $\begin{array}{c}\text { Zeylanicob- } \\
\text { della sp. }\end{array}$ & 3 & 16,66 \\
\cline { 2 - 4 } & Gill & $\begin{array}{c}\text { Dactylogyrus } \\
\text { sp. }\end{array}$ & 3 & 10 \\
\cline { 2 - 5 } & Mouth & $\begin{array}{c}\text { Zeylanicob- } \\
\text { della sp. }\end{array}$ & 4 & 13,33 \\
\hline
\end{tabular}

Table 5: The total Prevalence ectoparasites infected of female grouper fish.

site in mucous organs was found the value of $13.33 \%, 10 \%$ in the fins and $13.33 \%$ in the oral organs. The ectoparasite of Brooklynella hostilis prevalence was found the value of $16.66 \%$ in mucous organs only. The ectoparasites Dactylogyrus sp prevalence value was found of $10 \%$ It can be seen in table 5 . Almost the prevalence ecto parasite value was found highest in female compared in male grouper fish. Tihs result was similar according to Williams [2] in the ectoparasite prevalence category in Table 1, with the guidelines infection categories based on prevalence information.

The prevalence of Zeylanicobdella sp was found higher in the mucus, fins, oral organs were categorized as "frequent" infection. The ectoparasite from genus of Zeylanicobdella sp mostly was attacks the organs of fish. The are attacked of the parts of mucus in fish body, fins and the mouth organs of fish similiar with According to Nofasari., et al. [10] which stated higher prevalence of tparasite from the genus of Zeylanicobdella sp caused by several factors, ofirst is environmental factors, when the environmental conditions changes the temperature in water will unstable, leftovers than the fish can stress and the immunity will be decreases than the parasite can lead to the body of fish $[5,8]$. Some parasaite like monogeneous parasites can develop rapidly due to several factors, including high density, poor nutrition, poor water quality thus enabling the rapid development of parasites, where the high stocking density results in competition for space, food, and oxygen [10].

Meanwhile, the genus of Brooklynella hostilis some time was found in mucus organs and the called categorized as "sometime" infection. While the Genus of Caligus sp was found in the mucus organs are categorized as "frequent" infections. The genus of Dactylogyrus sp was found in the gill organs is categorized as "sometime" infection. The Genus of Dactylogyrus sp can attacked to the gill organs of fish. Based on the level of prevalence criteria according to Williams [2] the Dactylogyrus sp wsa found in Cantang Grouper is included in the category of sometime infections.

The living habitat of the parasite Dactylogyrus sp was found in the fish's gills and life cycle directly showing in body color and turn pale to the fish. This is in accordance with Mahendra and Nurbadriati [9] which state for the gills organsh of fish was directly related to the aquatic environment and the respiratory system and directly to related of heart circulation. For the gills are organs was continuously contact in the outside environment. The gills are gateway to the entry of nutrient sources because this organ directly connects to the external environment and the environment in body fish's and tissue structure, therefore for fish is very sensitive to toxic substances.

\section{Conclusion}

From the 30 male and female of Cantang Grouper fish was infected of ectoparasite parasite prevalence in mucus, fins, gill and 
mouth. The genuse was attack of body fish is Zeylanicobdella sp, Brooklynella hostilis sp and Dactylogyrus sp. There is 17 of male fish was infected of parasite and 13 of fish from $h$.

\section{Bibliography}

1. Jiet CW and N Musa. "Culture Techniques of Cantang grouper (Epinephelus fuscoguttatus-lanceolatus) at Floating Net Cages in Brackish Water Aquaculure Development Center, Situbondo East Java". Fisheries and Marine Scientific Journal 10.2 (2018): 70-75.

2. Williams E H J and L B Williams. "Parasites of Offshore Big Game Fishes of Puerto Rico and The Western Atlantic". Department of Natural and Environmental Resources. University of Puerto Rico. Puerto Rico (1996): 25-28.

3. Wiyatno F H., et al. "Identification and Prevalence of Ectoparasites in Grouper Rat (Cromileptes altivelis) in Floating Net Cages at the Marine Cultivation Management Unit of Situbondo". Fisheries and Marine Scientific Journal 4.1 (2012): 9-12.

4. Mahasri G., et al. "Ectoparasite worms intensity of Cromileptes altives rat grouper in floating net cages in Situbondo waters, East Java". Journal of Tropical Marine 22.2 (2019): 135-140.

5. Gusriyanti., et al. "Inventory of Parasites in Sunu Grouper (Plectropomus leopardus) Raised in Floating Cages". Aquatic Media 1 (2016): 15-26.

6. Wiguna DA. "Ectoparasite examination on Masamo Catfish (Clarias sp.) At the Center for Marine and Fisheries Technology Development, Sleman, Yogyakarta Special Region" (2016): 5-10.

7. Nofyan E., et al. "Identification and Prevalence of Ectoparasites and Endoparasites in Tilapia (Oreochromis niloticus) in Aquaculture Ponds in Palembang, South Sumatra". (2015): 1928.

8. Gani A., et al. "Study of Habitat and Food Habit of Rono Lindu Fish (Oryzias sarasinorum POPTA, 1905)". Journal of Science and Technology Tadulako 4.3 (2015): 9-18.

9. Mahendra and Nurbadriati. "Prevalence and Ectoparasite Intensity in Tawes Fish (Puntius javanicus) in Meunasah
Krueng Village, Beutong District, Nagan Raya Regency". Journal of Aquaculture 3.1 (2019): 21-28.

10. Nofasari N., et al. "Identification and Prevalence of Ectoparasites in Freshwater and Marine Fish in Bintan Fishery Cultivation Locations, Riau Islands". Aquaculture Intact 3.1 (2019): 92104.

\section{Assets from publication with us}

- Prompt Acknowledgement after receiving the article

- Thorough Double blinded peer review

- Rapid Publication

- Issue of Publication Certificate

- High visibility of your Published work

Website: www.actascientific.com/

Submit Article: www.actascientific.com/submission.php

Email us: editor@actascientific.com

Contact us: +919182824667

Citation: Yusni E., et al. "Identification of Ectoparasite and Prevalence Male and Female of Cantang Grouper Fish (Epinephelus fuscoguttatus $x$ Epinephelus lanceolatus) in Aquaculture Paluh Pisang Mas Deli Serdang, North Sumatera Province". Acta Scientific Nutritional Health 5.3 (2021): 61-68. 